\title{
Students' Adoption of Facebook in Higher Education: A gender-based Comparison
}

\author{
Cheng Ean (Catherine) Lee ${ }^{1, *}$, and Alison Yu Wei Chong ${ }^{2}$ \\ ${ }^{1}$ Department of Communication and Liberal Arts, Faculty of Arts, Sunway University, Malaysia \\ ${ }^{2}$ Faculty of Education, University of Malaya, Malaysia
}

\begin{abstract}
This paper aims to examine the gender differences of undergraduate students' educational use of Facebook. The objectives of the study include identifying male and female students' Facebook usage and assessing their perception on the usefulness and ease of use of Facebook in higher education. Using a quantitative research method, results reveal that male students have a higher frequency of Facebook visit (93.9\%). Male students are more competent (48.5\%) and more satisfied $(42.2 \%)$ in using Facebook in comparison to female students. Although there were marginal differences between males' and females' perception for both usefulness and ease of use of Facebook (with mean differences ranging from 0.01 to 0.33 ); the differences in their overall perception on the usefulness and ease of use of Facebook were not significant $(\mathrm{p}<.05)$. In conclusion, male students had a higher overall score on the perceived usefulness of Facebook in higher education, while female students had a higher overall score on the perceived ease of use of Facebook.
\end{abstract}

\section{Introduction}

With the increasing number of research on social media in higher education, the most common and popular social media tool used in higher education is Facebook [1]. Recent years have seen the proliferation of empirical research on Facebook use in higher education particularly in Malaysia [2, 3, 4, 5, 6, 7, 8, 9, 10,11]. Besides, prior literature revealed that the use and influence of social networking sites in students' daily lives are pervasive as they used it not only for social purposes but also for educational reasons [4]. Drawing on the literature, Facebook has the potential to be used as a platform for online academic discussions [2]; Facebook is used for informal learning [8]; Facebook complements the current teaching and learning practices [3, 7]; Facebook enhances teaching and learning practices in large classes [6]; and Facebook has a positive impact on students' academic performances $[9,10,11]$.

In addition, four research $[12,13,14,15]$ focus on investigating gender differences on academic uses of Facebook among undergraduate students because [12] claimed that 'differences in male and female communication are widely known, but peer reviewed research is difficult to find for social networking communication' (p. 89). Although [9] and [10] found no significant gender differences regarding the use of Facebook for academic

\footnotetext{
* Corresponding author: catherinelee@sunway.edu.my
} 
activities, [5] state that an academically viable sense of direction for future research on exploring Facebook especially information about gender differences is much needed.

Therefore, our study aims to examine the gender differences of students on the educational use of Facebook and to gauge their attitude towards adopting Facebook in the classroom. The two research questions guiding this study are: How male and female students differ in terms of Facebook usage? and What are the differences among male and female students' perception on the usefulness and ease of use of Facebook in higher education?

\section{Method}

We utilised a self-administered questionnaire with undergraduate students of a private university in the Klang Valley from 26 to 29 January 2015. The survey respondents were selected through purposive random sampling from students who use Facebook for educational purposes. The respondents were to provide their usage of Facebook, level of competency and satisfaction of using Facebook as well as perception on the effectiveness of adopting Facebook in higher education. The result of the survey was analysed using both descriptive and inferential statistics. A total of 71 questionnaires were collected with 64 questionnaires were usable $(90.14 \%)$. Of the total of 64 respondents, $33(51.6 \%)$ were males and $31(48.4 \%)$ were females. Majority of the respondents aged 18 to 24 years old $(87.5 \%, n=56)$, Chinese $(71.9 \%, n=46)$ and studying in the Faculty of Arts $(70.3 \%, n=45)$. Table 1 illustrates the demographic profile of the respondents participated in this study.

Table 1. Respondents' demographic profile ( $n=64)$.

\begin{tabular}{|l|c|c|}
\hline Gender & Frequency & Percentage (\%) \\
\hline Male & 33 & 51.6 \\
Female & 31 & 48.4 \\
\hline Age Group & & \\
\hline Below 18 & 7 & 10.9 \\
18-24 years old & 56 & 87.5 \\
25-44 years old & 1 & 1.6 \\
\hline Race & 5 & 7.8 \\
\hline Malay & 46 & 71.9 \\
Chinese & 4 & 6.3 \\
Indian & 9 & 14.0 \\
Others & \multicolumn{2}{|c|}{} \\
\hline Faculty & 10 & 15.6 \\
\hline Pre-U & 45 & 70.3 \\
Faculty of Arts & 3 & 4.7 \\
Sunway University Business School & 6 & 9.4 \\
Faculty of Science and Technology & $\mathbf{6 4}$ & 100.0 \\
\hline Total & \multicolumn{2}{|c|}{} \\
\hline
\end{tabular}




\section{Results and discussion}

\subsection{Differences in the use of Facebook between male and female students}

In answering research question one, Table 2 shows the differences in terms of Facebook use between male and female students. In general, nearly all male students $(93.9 \%, n=31)$ reported a higher frequency of visit to Facebook in comparison to female students $(80.6 \%$, $\mathrm{n}=25$ ). This result contrasts with $[12,15]$ because in their study, female students reported spending a greater percentage of daily Internet time on Facebook than their counterpart. However, in terms of their frequency of updating profile page on Facebook, the number of female students outrides the male students. $13(42.0 \%)$ female students claimed that they update their profile page quite often with at least once a week, whereas only ten $(30.3 \%)$ male students often updated their profile page. In regard to students' self-reported level of satisfaction and competency in using Facebook, the results unveil that male students were more satisfied $(42.2 \%, n=14)$ and more competent $(48.5 \%, n=16)$ in using Facebook for educational purposes compared to female students.

Table 2. Male and female students' use of Facebook.

\begin{tabular}{|c|c|c|c|c|}
\hline & \multicolumn{2}{|c|}{$\begin{array}{c}\text { Male } \\
(\mathrm{n}=\mathbf{3 3})\end{array}$} & \multicolumn{2}{|c|}{$\begin{array}{c}\text { Female } \\
(\mathbf{n}=31)\end{array}$} \\
\hline & Frequency & $\begin{array}{l}\text { Percentage } \\
(\%)\end{array}$ & Frequency & $\begin{array}{c}\text { Percentage } \\
(\%)\end{array}$ \\
\hline \multicolumn{5}{|l|}{ Frequency of visit $(n=64)$} \\
\hline $3+$ times daily & 27 & 81.8 & 16 & 51.6 \\
\hline $1-3$ times a day & 4 & $12.1 \%$ & 9 & 29.0 \\
\hline Once every few days & 2 & $6.1 \%$ & 4 & 12.9 \\
\hline Once a week & 0 & 0 & 1 & 3.2 \\
\hline Once every few weeks & 0 & 0 & 1 & 3.2 \\
\hline Less than once a month & 0 & 0 & 0 & 0 \\
\hline Others & 0 & 0 & 0 & 0 \\
\hline \multicolumn{5}{|c|}{ Frequency of profile update $(n=64)$} \\
\hline More than once a day & 1 & 3.0 & 3 & 9.7 \\
\hline Once a day & 2 & 6.1 & 0 & 0 \\
\hline Once every few days & 6 & 18.2 & 3 & 9.7 \\
\hline Once a week & 1 & 3.0 & 7 & 22.6 \\
\hline Once a month & 10 & 30.3 & 9 & 29.0 \\
\hline Once a few months/ Once a year & 10 & 30.3 & 7 & 22.6 \\
\hline Others & 3 & 9.1 & 2 & 6.5 \\
\hline \multicolumn{5}{|c|}{$\begin{array}{l}\text { Level of satisfaction of using Facebook } \\
(n=64)\end{array}$} \\
\hline Highly dissatisfied & 3 & 9.1 & 1 & 3.2 \\
\hline Moderately dissatisfied & 4 & 12.1 & 2 & 6.5 \\
\hline Neutral & 12 & 36.4 & 16 & 51.6 \\
\hline Moderately satisfied & 10 & 30.3 & 10 & 32.3 \\
\hline Highly satisfied & 4 & 12.1 & 2 & 6.5 \\
\hline \multicolumn{5}{|l|}{$\begin{array}{l}\text { Level of competency of using } \\
\text { Facebook }(n=64)\end{array}$} \\
\hline Not competent & 0 & 0 & 2 & 6.5 \\
\hline Somewhat competent & 7 & 21.2 & 7 & 22.6 \\
\hline Uncertain & 10 & 30.3 & 7 & 22.6 \\
\hline Competent & 10 & 30.3 & 10 & 32.3 \\
\hline Highly competent & 6 & 18.2 & 5 & 16.1 \\
\hline
\end{tabular}




\subsection{Differences between male and female students' perceived usefulness and ease of use of Facebook}

Finally, the second research question examines the gender differences of students' perception on the usefulness and ease of use of Facebook. Table 3 shows that both genders highly believed that Facebook is easy to use with the mean not less than 3.40 for each category. While the perception on the ease of use of Facebook was fairly moderate for both males and females, with the mean ranging from 3.15 to 3.48 on the former and 2.87 to 3.35 on the latter, neither males nor females held any of the perception categories with low scores.

Although there were differences between males' and females' perception for both usefulness and ease of use of Facebook, such differences were marginal, with the mean differences ranging from 0.01 to 0.33 . Despite these considerable differences, the results reveal that male students and female students did not significantly differ in their overall perception on both the usefulness and ease of use of Facebook $(p<.05)$. Even though no significant differences were found, males had a slightly higher overall score on the perceived usefulness of Facebook, while females have a higher overall score on perceived ease of use of Facebook.

Besides, as compared to female students, male students reported a higher score in all six $(100 \%)$ statements on the perceived usefulness of Facebook in higher education. On the other hand, females reported a higher score in four out of six $(66.7 \%)$ statements on the perceived ease of use of Facebook, excluding "it is easy for me to become skilful when using Facebook" and "learning to operate Facebook is easy for me".

Table 3. Differences in male and female students' perceived usefulness and perceived ease of use of Facebook.

\begin{tabular}{|l|c|c|c|c|c|c|}
\hline \multirow{2}{*}{} & \multicolumn{2}{|c|}{$\begin{array}{c}\text { Male } \\
(\mathbf{n}=\mathbf{3 3})\end{array}$} & \multicolumn{2}{c|}{$\begin{array}{c}\text { Female } \\
(\mathbf{n}=\mathbf{3 1})\end{array}$} & \multirow{2}{*}{$\boldsymbol{t}$} & $\boldsymbol{p}$-value \\
\cline { 2 - 6 } & $\mathrm{M}$ & $\mathrm{S} . \mathrm{D}$ & $\mathrm{M}$ & $\mathrm{S} . \mathrm{D}$ & & \\
\hline $\begin{array}{l}\text { PU Perceived Usefulness } \\
\text { PEOU Perceived Ease Of Use }\end{array}$ & 3.33 & 0.60 & 3.16 & 0.80 & 1.007 & 0.318 \\
\hline $\begin{array}{l}\text { PU1: Using Facebook enables me to } \\
\quad \text { complete the tasks more quickly. }\end{array}$ & 3.48 & 0.72 & 3.92 & 0.62 & -0.661 & 0.511 \\
$\begin{array}{l}\text { PU2. Using Facebook improves my } \\
\text { academic performance. }\end{array}$ & 3.15 & 0.62 & 2.87 & 0.89 & 1.478 & 0.145 \\
$\begin{array}{l}\text { PU3. Using Facebook increases my } \\
\text { academic productivity. }\end{array}$ & 3.36 & 0.78 & 3.03 & 1.11 & 1.387 & 0.171 \\
$\begin{array}{l}\text { PU4. Using Facebook enhances my } \\
\text { learning effectiveness. }\end{array}$ & 3.24 & 0.79 & 3.23 & 0.88 & 0.079 & 0.937 \\
$\begin{array}{l}\text { PU5. Using Facebook makes it easier } \\
\text { to } \quad 3.33\end{array}$ & 0.74 & 3.16 & 1.00 & 0.786 & 0.435 \\
\hline $\begin{array}{l}\text { PU6. Overall, I find Facebook useful as } \\
\text { an educational tool. }\end{array}$ & 3.42 & 0.79 & 3.29 & 1.13 & 0.551 & 0.583 \\
\hline
\end{tabular}




\begin{tabular}{|c|c|c|c|c|c|c|}
\hline $\begin{array}{c}\text { PEOU1. Learning to operate Facebook } \\
\text { is easy for me. }\end{array}$ & 4.03 & 0.88 & 4.03 & 0.80 & -0.009 & 0.993 \\
$\begin{array}{c}\text { PEOU2. I find it easy to get Facebook } \\
\text { to do what I want it to do. } \\
\begin{array}{c}\text { PEOU3. I find Facebook flexible to } \\
\text { interact with. }\end{array}\end{array}$ & 3.79 & 0.70 & 3.81 & 0.95 & -.090 & 0.929 \\
$\begin{array}{c}\text { PEOU4. My interaction / activity on } \\
\quad \begin{array}{l}\text { Facebook is clear and } \\
\text { understandable. }\end{array}\end{array}$ & 3.67 & 0.89 & 3.94 & 0.77 & -1.287 & 0.203 \\
$\begin{array}{c}\text { PEOU5. It is easy for me to become } \\
\text { skilful when using Facebook. }\end{array}$ & 3.58 & 0.97 & 3.48 & 0.96 & 0.380 & 0.705 \\
\hline $\begin{array}{c}\text { PEOU6. Overall, I find Facebook easy } \\
\text { to use. }\end{array}$ & 4.06 & 0.83 & 4.19 & 0.54 & -0.755 & 0.453 \\
\hline
\end{tabular}

\section{Conclusion}

Our study presents two main findings that explored the use of Facebook by both male and female students of a private university and their perception on the effectiveness of adopting Facebook in higher education. Firstly, majority of the students were heavy users of Facebook who paid frequent visit to Facebook for more than three times in a day with male students reported having a higher frequency of visit, more satisfied and more competent in using Facebook for educational purposes in comparison to female students. Secondly, there were marginal differences between males' and females' perception for both usefulness and ease of use of Facebook for educational purposes; yet it did not significantly differ in their overall perception on both the usefulness and ease of use of Facebook in higher education $(\mathrm{p}<.05)$.

To conclude, in view with the above, it is clear that there was no gender difference in using Facebook in higher education. Besides, there were no significant differences in their overall perception on the usefulness and ease of use of Facebook as an educational tool. Yet for effective use of Facebook in higher education, positive attitude of both male and female students are crucial.

This paper is part of the research project funded by Sunway University Internal Research Grant Scheme 2014 (INT-FOA-DCLA-0114-11).

\section{References}

1. S. Neier, L.T. Zayer, J. of Marketing Edu, 37 (2015).

2. T. Lim, Turkish Online J. of Distance Edu, 11 (2010).

3. S. Hamid, J. Waycott, S. Chang, S. Kurnia, Ascilite, (2011).

4. N.M. Almadhoun, F.W. Lai, P.D.D. Dominic, An examination of social networking sites usage among the students in the Malaysian universities. ICMEF Proceeding, (2012).

5. H.H. Hamsan, M.N. Kumar, Pertanika J. of Social Science \& Humanities, 21 (2013).

6. R.R. V. Rasiah. Social and Behavioral Sciences, 123 (2014). 
7. C.E. Lee, S.V. Sangaran Kutty, S.P. Wong, Exploring the use of Facebook in the classroom: A Malaysia case study. Proceedings for $2^{\text {nd }}$ European Conf. on Social Media ECSM, (2015)

8. A. Hamat, M.A. Embi, H.A. Hassan. Int. Edu Studies, 5, 3 (2012)

9. A.M. Helou, N.Z. Ab. Rahim, The influence of social networking sites on students' academic performance in Malaysia. Proceedings for the Int. Conf. on Internet Studies, $1-18(2011)$

10. A.M. Helou, Z.Z. Ab. Rahim, Z.Z. \& Oye, N.D. Int. J. of Social Networking and Virtual Communities, 1 (2012)

11. N. Din, S. Yahya, S. Haron, Information retrieval and academic performance among Facebook users. AicE-Bs 2012 Cairo ASIA Pacific Int. Conf. on EnvironmentBehaviour Studies, 68 (2012)

12. S.H. Thompson, E. Lougheed. College Student Journal, 46 (2012)

13. G. Grosseck, R. Bran, L. Tiru, Dear teacher, what should I write on my wall? A case study on academic uses of Facebook. WCES 2011 (2011)

14. A.K. Alhazmi, A. Abdul Rahman. AISS, 5 (2013)

15. A. ul Haq, S. Chand. Bulletin of Edu and Research, 34, 2 (2012) 